\title{
Metaphor and urban studies-a crossover, theory and a case study of SS Rotterdam
}

\author{
Peter Nientied ${ }^{1,2^{*}}$
}

\begin{abstract}
Metaphors are used in various ways; at the surface for framing a message (systems of language) and below the surface metaphors are related to the ways we think and act. In this paper we will explore, below the surface, the relationship between metaphors and urban studies. From an analysis of metaphors used in urban studies, it will be concluded that, so to speak, every new phenomenon gets a new metaphor around which theoretical notions are developed. Indeed, 'a 1000 flowers bloom'. This paper will study what urban studies can learn from organization theory. In particular, the question whether the set of metaphors from one of the classics in organizational theory—namely Gareth Morgan's Images of Organization — can inform urban studies, can be used to grasp, to 'read' cities. After exploring theoretical notions, the case study is the SS Rotterdam, a former luxury cruise ship that that came back to Rotterdam to serve as a catalyst for urban development. Different metaphors of Morgan's set are applied in this case study to get a better understanding of the management, decision making, culture and political system. It will be concluded that Morgan's set of metaphors looks promising for urban studies and recommendations are made about research lines along which further theoretical and empirical work may be carried out.
\end{abstract}

Keywords: Metaphors, Urban theory, Organization theory, Rotterdam

\section{Background}

Cities are many things at once! They are complex and multifaceted. They are paradoxical. ${ }^{1}$

"To speak of a city as a whole is to speak in metaphors."

Latham (2008) suggests that a new, and more inventive, set of metaphors is needed in addition to those we are used working with. Without new metaphors-and the shift in style of thinking that new metaphors bring with them-urban studies will be unable to do proper justice to the heterogeneity and complexity of cities. Meager (2015) submits a similar suggestion; there is a need for new metaphors or figurations that help to think creatively about urban conditions and the possibilities for political interventions. This article addresses the question of metaphors in urban studies, in a novel manner. An attempt

\footnotetext{
${ }^{*}$ Correspondence: nientied1@chello.nl

${ }^{1}$ Polis University Tirana, Rruga Bylis 12, Autostrada Tiranë-Durrës, Km 5, 1051 Tirana, Albania

Full list of author information is available at the end of the article
}

will be made to apply metaphors borrowed from organization theory and explore whether this makes sense for urban studies. It will be argued that there are some plausible motives for such crossover; like cities, organizations are complex and heterogeneous human institutions. The article will first examine how metaphors are used in urban studies. It will become clear that a multitude of metaphors is employed, in various manners. Then an established set of metaphors used in organizational studies is borrowed, examined and used in a case study. This set of metaphors used is from one of the classics in organizational theory, namely Gareth Morgan's Images of Organization (Morgan 2006). So, the metaphors for urban studies that will be used in this article can be seen as crossover from organization theory. Morgan portrays organizations through the metaphors: (1)

\footnotetext{
${ }^{1}$ Morgan starts Chapter 10 of his book with 'Organizations are many things at once! They are complex and multifaceted. They are paradoxical" (Morgan 2006, 337). Stieber $(2012,5)$ says "As urban historians and sociologists have taught us, a city is an amalgam of many simultaneous social, political, economic and cultural processes."

2 Stieber $(2012,28)$.
}

Springer Open

(c) The Author(s) 2016. This article is distributed under the terms of the Creative Commons Attribution 4.0 International License (http://creativecommons.org/licenses/by/4.0/), which permits unrestricted use, distribution, and reproduction in any medium, provided you give appropriate credit to the original author(s) and the source, provide a link to the Creative Commons license, and indicate if changes were made. 
the organization as a machine; (2) the organization as an organism; (3) as brains; (4) as cultures; (5) as political systems; (6) as psychic prisons; (7) as flux and transformation, and; (8) as instruments of domination.

The methodology of the study is twofold. The first component is an extensive literature search on metaphors and urban studies, and an analysis of the findings. The result is presented in "Metaphors and the city". The second component is a study of documents and other sources reporting on SS Rotterdam and a secondary analysis of especially the reports of the parliamentary investigation (Tweede Kamer 2008, 2014) on the functioning of the housing corporation, and the case of SS Rotterdam was part of that investigation. In this paper will we not go into questions about the theory of metaphors; we refer to Lakoff and Johnson (2003) standard volume on metaphors, while the work of Gerber and Patterson (2014) on metaphors in architecture and urbanism may serve as a starting point for urban studies.

The notion of working with metaphors is understanding and experiencing one kind of thing in terms of another (Lakoff and Johnson 2003; Köveczes 2010). "Metaphor operates through the juxtaposition of images (e.g. 'A is B'; 'the organization is a machine'), where one element is understood in terms of another and provides a novel way of grasping, seeing and acting in any given situation in a manner that often ends up challenging takenfor-granted modes of understanding. The overall process is creative and expansive." (Morgan 2016, 1030) Solesbury $(2013,6)$ states that the way we think about cities is strongly shaped by metaphors. The city as a community for example, implies a commonality of values, identity and interests that help people to live together. But shift to a metaphor like 'divided cities', and differences on the basis of location, class, income and ethnicity or religion are immediately implicit.

Metaphorical linguistic expressions are well worn, clichéd ways of talking about abstract domains (Köveczes $2010,34)$. Solesbury $(2013,5)$ even talks about 'dead metaphors', ones that are in such common usage that they go unnoticed. Conceptual metaphors are seen as deeply entrenched ways of thinking about or understanding an abstract domain. For urban studies, this is the interesting field of research in the current article. Geary (2012, 3) states "Metaphor is a way of thought long before it is a way with words". Todolí $(2007,52)$ concludes: "For a long time metaphors were seen as a rhetorical device and more specifically as a matter of poetry. Today, however, many cognitive linguists and analysts of discourse recognize that metaphors play a central role in thought and structure our perception and understanding of reality." In five experiments, Stanford researchers Thibodeau and Boroditsky (2011) explored how metaphors influence the way that we reason about complex issues and forage for further information about them, and found that that even the subtlest instantiation of a metaphor (via a single word) can have a powerful influence over how people attempt to solve social problems like crime and how they gather information to make "well-informed" decisions.

A set of metaphors used in organization theory is used for urban studies. The application of metaphors developed in organization theory, goes with a question of comparability, for cities and organizations are different objects of course. First, according to Scott and Storper (2015) a city can be understood in terms of dynamics of agglomeration/polarization, and the unfolding of an associated nexus of locations land uses and human interactions (and a number of scholars would not agree to this definition). An organization can be understood as a human institution that is structured and managed to goals such as collective goals, the goals of an owner or public needs (and a number of scholars would not agree to this definition). Second, unlike most organizations, cities have no unity of command based on organizational goals or ownership, which applies to all members (but neither have self-managed teams or cooperatives). And the average life span of cities and organizations differs. However, cities and organizations as objects of study have some important features in common. Both cities and organizations can be seen as human institutions, forms of multifaceted human organization functioning in complex environments. Second, cities and organizations are built on formal and informal rules, rules which provide for rationality (Clegg and Kornberger 2016). And both cities and organizations go on while their members changethey have an embedded structural reality that endures irrespective of their members and visitors. Thirdly, both cities and organisations are heterogeneous and complex. Cities can be small and simple and have one main function, or can have the size and complexity of a metropolis. Organizations vary a lot too, from small and simple to big and complex. But for both cities and organisations, small does not mean simple. As human institutions, even the smallest city or organisation can entail all sorts of complexities.

Bridges between organizational and urban theory are being constructed (to use a metaphor). Van Es and van Rossum (2016) elaborate in their volume on The city as organisation, questions such as 'which knowledge from organisation theory and change management can deliver a positive contribution to the development of the city', and 'which way of organisation and which attitude of actors contribute to the city as organism. Case and Gaggiotti (2014) explore the way in which uses or abuses of urban metaphors can inform differing polities and ethics of human organization. Our search is a bit different: 
can organisation theory be used for urban studies? The notion of crossover is well known in innovation studies (Vullings and Heleven 2015).

\section{Metaphors and the city}

The use of metaphors in urban studies is not new; for long metaphors have been widely used in urban theory and urban planning (Gerber and Patterson 2014; Secchi 2014; Stieber 2012). Gerber (2014, 18-19) notes that architecture and urbanism have elusive and hard to grasp objects. Metaphors help to understand what is at the core of these disciplines, which can only partially be captured by language. Popular metaphors include the portrayal of a city as a concrete jungle, as a hybrid city, as a contested or divided city, as a person, or as a moving city. Metaphors vary in their degree of conventionality; some are rather direct, like the 'soft and hard city', while others are more poetic, such as "Cities are a never ending process, a constant fight between the oasis and the desert. They deploy edge logic, a sort of 'theatre of rise and fall." (Martinez 2014, 649). Rem Koolhaas said on Dubai "the ultimate tabula rasa on which new identities can be inscribed." (Bernstein 2013).

There is a wide and creative variety of metaphors to depict and understand city phenomena. Solesbury (2013, 6) suggests "The way we think about cities is strongly shaped by metaphors. Five recur in many variations: the city as a community, as marketplace, as battleground, as machine and as organism. These are extended metaphors, that is, they serve to structure the whole concept of the city with many dimensions and levels of meaning". There are many more metaphors and interpretations, a wide variety is applied. From the metaphor of the creative city (Laundry 2008) to the city as Interwoven cities, understood in terms of fabrics, cloths, threads, and elaborate in a scheme with 'seams, cuts and point of friction' (Magee 2016; cf. Skivko 2013). From the metaphor of the pop-up city to discuss 'city-making in a fluid world' (Beekmans and de Boer 2014) to provocative metaphoric constructions found in the gentrification discourse (Gregory 2012). Haar (2007) explains the metaphor 'ecological city'; natural processes were embraced as metaphors for the city rather than as its underlying metabolism. Newell and Cousins (2015) discuss the urban metabolism metaphor in detail. Pickett et al. (2004) discuss the metaphor 'resilient cities', and see 'resilience' as an integrative metaphor, linking the disciplines of ecology and design. Urban resilience has become an important topic in Europe (EU 2016).

Spatial metaphors are commonly used (Duhr et al. 2010, 59 ff.). Mehmood (2010) analyses evolutionary metaphors in urban planning. A metaphor is a support to recognize and remember spatial concepts. A well know Dutch metaphor is in the name Het Groene Hart (the Green Heart), a more rural space surrounded by cities.
The Amazon is depicted as the world's lungs, and Copenhagen's planning past has the 'Five finger plan'. The urban DNA is biological metaphor (Wu and Silva 2011).

An expressive example of how metaphors can work in practice, is provided by Todolí (2007). He studied disease metaphors used in urban planning in Spain, to hide social change (sanitizing is in Spain what gentrification refers to), with urban surgery as intervention [and only specialist surgeons (=planners) can do that]. In the Netherlands, the metaphor of 'rotten tooth' is common language for obsolete ugly buildings, backward areas etc., and it helps to make clear to the public what needs to be done (the urban 'dentist' will have to pull the tooth).

A variety of theories is used for reading and understanding cities. For example, in the titles of chapters of four recent volumes on urban studies, of Bridge and Watson (2013), Enderson and Jayne (2012), Paddison and McCann (2014), and Parker (2015), we come across metaphors as in the next Table 1, and in the texts of the volumes many more metaphors can be found.

Metaphors are not just language; they are a style of thinking. The 'liquid city' and the 'solid modern city' is not just language; it is a way of perceiving the city through the concept of liquid life/liquid modernity of Baumann (2005), as Franklin (2010) does. 'The Green Heart' is not just planning language; it has emotional and rational connotations, it influences behaviour. And the metaphor of 'the rotten tooth' makes it clear what has to be done: pull it. It is collective sense making for an urban redevelopment project. In short, metaphors are concepts that frame thinking and feeling.

We started our article with a reference to Latham (2008) who called for new metaphors. Many new metaphors have emerged in urban studies and urban theory, and it looks like that a 1000 flowers bloom. We agree with Gerber (2014), who states that architecture and urbanism have elusive and hard to grasp objects. This renders urban theory and urban studies more complex-every new phenomenon gets a new metaphor around which theoretical notions are developed, so to speak. The smart city and the resilient city are contemporary examples.

\section{Table 1 Selected city metaphors}

\begin{tabular}{ll}
\hline The functional city & The smart city \\
The networked city & The sinful city \\
The slumdog city & The capitalist city \\
The flexible city & The polarised city \\
Toxic cities & The globalising megalopolis/global city \\
Digitally dived cities & The post-crash city \\
Software sorted cities & The liquid city \\
'New'gentrified city & Just cities
\end{tabular}


This is a challenge for urban theory. In the next sections, we will attempt to make a cross-over from organization theory, and study whether a set of widely accepted metaphors developed by Morgan (2006) can help the study of city making, and create some order.

\section{Morgan's images of Organization}

Garreth Morgan's book 'Images of Organization' was published in 1986. The book became a classic in organization theory. It has been revised and updated in 2006, but the core scheme of metaphors has remained the same. Morgan's simple premise is $(2006,4)$ “... all theories of organization and management are based on implicit images or metaphors that lead us to see, understand, and manage organizations in distinctive yet partial ways." Morgan states that a metaphor is much more than just a devise for embellishing discourse; the use of metaphor implies a way of thinking and a way of seeing that pervade how we understand our world generally. Morgan claims that all theory is metaphor. Theory may be capable of creating valuable insights, but may also give incomplete, biased and potentially misleading information. Metaphor is inherently paradoxical. It can create powerful insights that also become distortions, as a way of seeing through a metaphor (and theory) becomes a way of not seeing. Barter and Russel (2013), as an example, confirm this in their study on the concept of sustainable development. They conclude that the dominant machine and organism metaphors impede progress towards sustainable development because they perpetuate a story that dehumanises and de-prioritises humans at the expense of the organisation which in turn becomes a rarefied and prioritised subject.

Morgan (2006) says about his approach in the book "It has a clear point of view: that metaphor is central to the way we "read," understand, and shape organizational life. But at no point will you find that view being brought down to advocacy of a single perspective. There are no right or wrong theories in management in an absolute sense, for every theory illuminates and hides." Morgan stresses that different metaphors have a capacity to tap different dimensions of a situation, showing how different qualities can co-exist. Morgan urges managers to use a range of metaphors, for "Limit your thinking and you will limit your range of action". $(2006,340)$ Much more can be said about the metaphors of Morgan, as he himself did $(2011,2016)$, but that is beyond the scope of this paper.

Morgan's metaphors and selected associated concepts are summarized in Table 2.

By way of example, this set is translated into examples of theories that can be applied to one single organization in Table 3, be it giants like BP or Ikea or a health clinic around the corner.
Morgan's point is that these metaphors and theories are different ways of grasping an organisation; they show different aspects of the organisation. Multiple perspectives offer a broader perspective. Not all metaphors are relevant in all situations - that will depend on the questions asked, on the real world situation.

A number of Morgan's metaphors are well known too in urban studies, like the metaphors of the machine, the organism and the political system. And, to an extent, culture and domination too. However, a few pointers render Morgan's approach valuable for urban studies. First, Morgan presents this set of metaphors as root metaphors. Morgan (2006) says in his updated book that many new metaphors have emerged since 1986, but this has not moved him to revise the set of root metaphors. He adds (Morgan 2016, 1035) “..when discussing root metaphors, we are again using a metaphor to discuss metaphor. The whole concept of 'root' evokes an image of something that is grounded and from which other things stem and grow." Rather than searching for the foundations of knowledge, that will be the direction of a quest for root metaphors, Morgan suggests $(2016,1036)$ ".. to think about all metaphors in terms of their generative potential and judge the power of a particular metaphor in these termsnamely, in terms of the insights and potential implications, actions and impacts that flow from the richness and power of the metaphor and the potentials it creates." And for that reason Morgan did not modify the set of 8 root metaphors. A second point is that Morgan suggests that metaphors are not right or wrong, but that they illuminate and hide-show aspects of the nature of organizations and organizational life, and that using multiple metaphors will give better insights into organizations. In other words-it is better to use combinations of metaphors as starting point for addressing complex questions. In an era of academic specialization, this is not common standpoint. And third, in the field of organization theory and especially in management practice, metaphors like the psychic prison and flux and transformation, are not much acknowledged. The reason for that is presumably that they are outside the paradigm of logical, linear thinking, they do not focus on getting better results for organizations. But, what organizations as human institutions do not want to see, may be a quite critical thing.

Aligning with these 3 pointers, three questions emerge for urban studies: (1) which metaphors have most generative power and could together function as a set of root metaphors?; (2) how can metaphors be combined to generate better insights into urban questions, and (3) which metaphors are less appreciated but could lead to meaningful understanding? 
Table 2 Morgan's metaphors and key concepts

\begin{tabular}{|c|c|}
\hline Metaphor, organisations as: & Key concepts \\
\hline 1. Machines & $\begin{array}{l}\text { Mechanistic organization, scientific management, bureaucratic organizations, goals and objectives, rationality, effi- } \\
\text { ciency, clarity, order, programs, inputs and outputs, standardization, production, measurement and control }\end{array}$ \\
\hline 2. Organisms & $\begin{array}{l}\text { Organizational needs, open systems, living systems, environment, adaptation, life cycles, recycling, needs, open } \\
\text { systems, evolution, survival of the fittest, organizational health and development, contingency theory (adapting } \\
\text { organization to the environment) }\end{array}$ \\
\hline 3. Brains & $\begin{array}{l}\text { Learning, parallel information processing, distributed control, cybernetics, holographic brains, intelligence, feedback, } \\
\text { requisite variety, knowledge }\end{array}$ \\
\hline 4. Cultures & Values, beliefs, rules, rituals, diversity, traditions, history, shared vision and mission, enactment of shared realities \\
\hline 5. Political systems & $\begin{array}{l}\text { Systems of government, interests, power, hidden agendas, authority, alliances, party-line, censorship, gatekeepers, lead- } \\
\text { ers, conflict management }\end{array}$ \\
\hline 6. Psychic prisons & $\begin{array}{l}\text { Conscious and unconscious processes, repressed sexuality, anxiety, projection, coping \& defence mechanisms, pain } \\
\text { and pleasure principle, dysfunction, the unconscious }\end{array}$ \\
\hline 7. Flux and transformation & $\begin{array}{l}\text { Autopoiesis, constant change, dynamic equilibrium, flow, systemic wisdom, attractors, chaos and complexity, dialectics, } \\
\text { paradoxes }\end{array}$ \\
\hline 8. Instruments of domination & $\begin{array}{l}\text { Exploitation of employees, class, control, work hazards, workaholism, alienation, repression, imposing values, mainte- } \\
\text { nance of power, force, divide and rule, discrimination, multinationals as world power }\end{array}$ \\
\hline
\end{tabular}

Table 3 Morgan's metaphors and examples of theory

\begin{tabular}{ll}
\hline Metaphor & Example of theory and application \\
\hline $\begin{array}{ll}\text { 1. Machine } & \text { Weber's bureaucracy, applied to organizational design and structure } \\
\text { 2. Organism } & \text { Open systems theory and contingency theory, applied to organization and its environment } \\
\text { 3. Brains } & \text { Theory of learning organizations, applied to knowledge management and learning principles } \\
\text { 4. Culture } & \text { Theory of organization culture, applied to enactment of shared reality (mission, behaviour, shared frames of reference) } \\
\text { 5. Political system } & \text { Theory of organizational politics, applied to interests, conflicts, leadership } \\
\text { 6. Psychic prison } & \text { Theory of group think, applied to decision making } \\
\text { 7. Flux and transformation } & \text { Theory of chaos and complexity, applied to leadership, strategy and management of change } \\
\text { 8. Domination } & \text { Theory of social domination and control: applied to companies influencing government, employees, consumer } \\
& \text { preferences, etc }\end{array}$ \\
\hline
\end{tabular}

a On the one hand the trap of favored ways of thinking that can lead to the decline of an organization, e.g. Kodak did not want to believe in digitalization, European companies did not want to believe in Japanese'just in time' manufacturing. On the other hand the realm of the unconscious-Frederick Taylor, the creator of what was called later 'scientific management' was totally preoccupied with control, was an obsessive, compulsive character (Morgan 2006, 212)

Attention may now turn to the case study of SS Rotterdam, a ship meant to be a catalyst of urban renovation.

\section{SS Rotterdam ${ }^{3}$}

SS Rotterdam (steam ship) is a $227 \mathrm{~m}$ long ship that that came back to the port city of Rotterdam to serve as an object with value for the economy and society, as

\footnotetext{
3 There are many sources (in Dutch) on the SS Rotterdam and its history. On Youtube, various short (mostly historic) videos can be found on SS Rotterdam. The link http://www.ssrotterdam.nl is en entry point to getting to know the ship. A visit is possible through Google Streetview. In the series 'Rotterdam forgotten stories', http://www.vergetenverhalen.nl/2015/09/23/ het-ss-rotterdam-de-titanic-van-woonbron/ is a good reference. Lemstra (2004) gives insight into the early stages of decision making and the attitude of the municipality regarding the SS Rotterdam. The report of the parliamentary investigation Tweede Kamer (2014) is a critical source, earlier reports (Tweede Kamer 2008, 2009) are relevant too. There is limited information of urban development side of SS Rotterdam, SEV (2010) is an exception, but this report was made for the then already criticized housing corporation Woonbron. See Programmabureau NPRZ (2015) for a current plan of Katendrecht.
}

a catalyst for the development of the Katendrecht area of Rotterdam. SS Rotterdam is not an ordinary ship for Rotterdam; it is an icon, nicknamed 'La Grand Dame.' SS Rotterdam started to sail in 1958 and its last trip was made in 2000. The demands in the cruise industry changed-SS Rotterdam became too small and lacked the required 5 star luxury. The ship ended up in a dock in Freeport (Bahamas). Various private and public parties in Rotterdam were interested in the ship, including the very active Rotterdam foundation for maritime heritage (Stichting Behoud Stoomschip Rotterdam). With support from the Port Authority of Rotterdam, a business man acquired the ship in 2003 (Lemstra 2004). He went bankrupt in 2004 (not because of the ship), and the Port Authority became temporary owner. At the request of the Port Authority and the municipality, Woonbron Housing Corporation and investment company Eurobalance bought the ship. The ambition for the ship was to create various social housing and education 
facilities and a function as a tourism spot. Due to the business case, this ambition was soon changed into more commercial use.

Anchoring the ship along the quay of the neighbourhood Katendrecht, signified an investment into urban renewal of this part of Rotterdam. It fit well in the urban development plans of the Municipality of Rotterdam. In the early 1990s, the redevelopment of the Kop van Zuid area started, a derelict harbour area. As this big urban project progressed, attention turned to the nearby area of Katendrecht, an area with a troublesome history ( van der Ent 2015). SS Rotterdam was seen as a very attractive factor for upgrading the Katendrecht area (Fig. 1).

After the acquisition of the ship, a complete renovation project was started. The ship was repainted in its original colours and anchored in Rotterdam in 2008. It was opened to the public in 2010 (Fig. 2).

The nice story, however, developed into a small nightmare from 2005 onwards. The renovation cost much more than budgeted: $€ 256$ million instead of the initially budgeted $€ 24$ million (!), due to removal of asbestos found in the ship and other issues. The graph below show the amount of the investment (Fig. 3).

After a political row (cf. Tweede Kamer 2008), the Minister responsible for the housing sector ordered strict supervision of the project and nominated a manager. But that was already too late. The supervisory board of Woonbron resigned in 2009 and later the director too. In 2013 the ship was sold to Westcord hotels for almost $€ 30$ million. Woonbron had to take the serious loss of $€ 227$ million, to be financed through the sale of social housing units. The ambition of Woonbron Housing Corporation to create social value for a redevelopment area in the southern part of Rotterdam ended in commercial

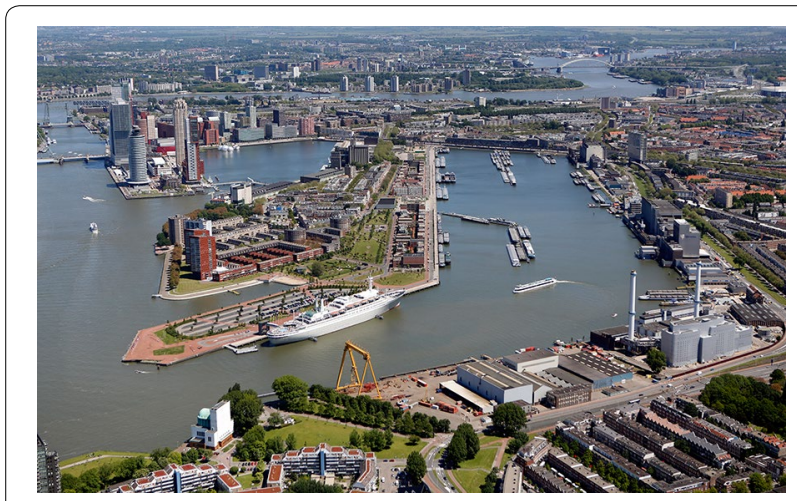

Fig. 1 SS Rotterdam in the urban environment. (photo: (c) R. Dijkstra, used with permission)

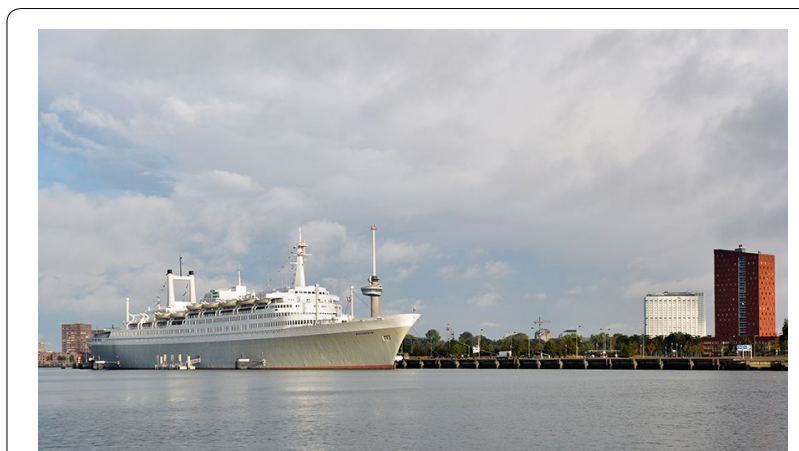

Fig. 2 SS Rotterdam. (photo: Peter Nientied)

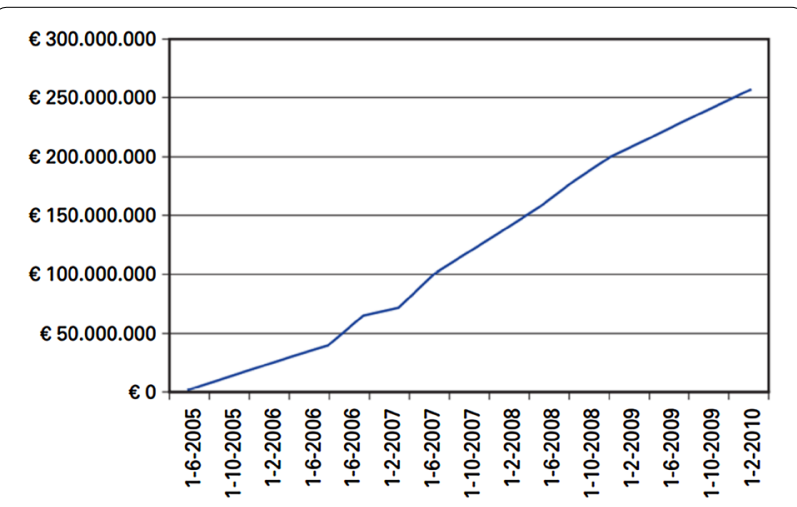

Fig. 3 Investment in SS Rotterdam

value for a hotel chain and tourism value for the city. The case of SS Rotterdam was part of a parliamentary investigation into the management of housing corporations (Tweede Kamer 2014) and has been analysed mainly from that angle.

Of course, this is just a summary of the case, one can imagine that the case contains rich details. The question now is which metaphors could best be used. The method proposed by Morgan (2006) suggests two stages: first is a diagnostic reading that strives to gain as comprehensive an understanding as possible, accompanied by a critical evaluation that integrates key insights. How to use the knowledge generated, depends on the point of view and the interests that we bring to the task of understanding (an academician looks in a different way that a consultant of political advisor). Morgan suggest that after the critical evaluation a storyline is developed, which helps to prioritize the insights into different metaphors. The storyline-from the objective of examining Morgan's metaphors for urban studies, is, briefly, 'SS Rotterdamthe silent story'. To this end we use four of Morgan's 
metaphors to look at this case: the machine, culture, psychic prison, and the political system. ${ }^{4}$

\section{Machine}

The machine metaphor, a well-known and leading metaphor in urban development and city making-could help to understand the project as a machine, with a proper design, with management and control. In the development process of SS Rotterdam, the mechanistic and rational logic was only modestly developed. The project was ill conceived, decision making was fuzzy, and project management was poor, as one can imagine on basis of the costs which turn out to be 10 fold the initial budget. Time upon time, the budget estimates for the renovation of the ship had to be increased. The housing corporation lacked experience in renovation projects of turning a cruise line ship into new urban use. Risks were noted, discussed, but not acted upon. The SS Rotterdam case tells us that a rational, clear and efficient development approach, and 'plan-organize-control', would have helped a lot. The case also shows that mechanistic approaches to organization of urban redevelopment do not work well under conditions that are not machine-like, when tasks are new and the levels of uncertainty and number of actors involved are high. The municipality was responsible for improving the quay in a structured manner, a routine project with low risks, on basis of calculated budgets. That did not give problems. But the complex renovation of a unique ship by a housing corporation was a different matter. The housing corporation was used to managing big projects, but in housing rather than ship renovation.

The machine metaphor illustrates just a small part of the story; additional metaphors are needed to better understand the case. The machine metaphor informs us about rational and planned organization, it cannot give a good explanation for the lack of planning and rationality.

\section{Culture}

Through the metaphor of culture, a meaningful element of urban reality can be grasped. The SS Rotterdam was (and is) more than a ship, or now a hotel with conference facilities or a tourism attraction for the city of Rotterdam. It was experienced by Rotterdam's citizens as an icon filled with emotional value. It was (and is) a symbol of the post war reconstruction of a city that was destroyed during WWII and experienced post war reconstruction.

\footnotetext{
${ }^{4}$ A full explanation this selection would require too much space. Very briefly: the organism metaphor suggest that the SS Rotterdam project was drifting out of alignment with the external environment, but this is better explained through the psychic prison metaphor. The domination metaphor does not give rich insights, the flux and transformation metaphor would focus on the object of the ship being used for urban development purposes, and the brain metaphor would focus on the resistance to learn lessons and adapt.
}

Indeed, Rotterdam's citizens were proud to have the ship back. When the ship entered the harbour of Rotterdam to be anchored in 2008 (at that time the poor management of the project was already widely discussed in the media), thousands and thousands of people (including the author of this paper) stood on the quays to welcome the ship, some of the older generation men who had worked in the harbour, with tears in their eyes. Various books have been written on the SS Rotterdam. Pride, nostalgia, hope for the future of Katendrecht renovation area, were strong elements of the culture and served as an enactment of a shared reality. And it was more than popular pride and nostalgia in the optimistic times before the economic crisis, a period in which Rotterdam made progress in its urban redevelopment plans. With Porto, Rotterdam was selected as cultural capital of Europe in 2001-and that was widely felt as recognition and a stimulus to go make next steps in realising the ambitions of the city. SS Rotterdam was conceived as a catalyst for urban redevelopment of Katendrecht area, which was a logical extension of the successful Kop van Zuid project.

The culture metaphor tells us that times were optimistic and that Rotterdam loved the initiative of SS Rotterdam. Culture depicts the context, but does not take decisions. The metaphor of the psychic prison helps to understand more about what actually took place.

\section{Psychic prison}

The psychic prison helps to understand a multi-layered situation: - the boardroom; -the context of government; and-the professional and academic context. Looking backwards, it can be concluded that in their hearts, everybody loved the initiative (also Ministers and members of parliament). KRO Brandpunt television program ${ }^{5}$ interviewed a member of the Supervisory Board of the housing corporation, and others, like the project managers, who were involved in the process. The picture that emerges is rather astonishing. Driven by optimism and supported by local government, public opinion, favourable economic climate, Woonbron's director and Supervisory Board alike, embraced the initiative. The sphere in the board room was 'euphoric'; it was a group process that can be explained by group emotion rather than group thinking. Looking back and from outside in, the psychic prison gives a clear representation: board members and director being loyal to one another and not creating 'difficulties' in the board room, thereby killing any criticism. Obvious risks were not taken serious. Because of prestige and backed up by a sound financial position, the director and supervisory board continued the project and step by step saw their initially

\footnotetext{
${ }^{5}$ The film is unfortunately not available any more or internet, it was removed by KRO Brandpunt early 2016 .
} 
planned €24 million budget, increase to more than $€ 65$ million and to $€ 136$ million in 2007. At a point of time (2006), the supervisory board came to disagree with the director. The supervisory board demanded a risk analysis. Deloitte Advisory prepared this analysis (2007), warned against serious risks and concluded that the business case could still be positive despite the much higher investments needed. It proved to be wrong. On 30 October 2008 the headline of the national newspaper Telegraaf was 'SS Rotterdam looks like a financial Titanic.' What has become clear is that the director of Woonbron pushed the project and in his ambition and optimism, ravished the corporation into a financial disaster, according to Gerrichhauzen et al. (2014). The supervisory board did not stop him, the Ministry acted too little and too late, and the municipality stated that it was not financially involved and not responsible. It became clear afterwards, that poor decision making had taken place.

The psychic prison metaphor is not to be confined to the board room. Although the municipality later played down its role (it had no direct financial involvement, the responsible Alderman stated), it did support the project through moral backing, an attractive contract for the quay and parking, and improvement of the Katendrecht area, as SS Rotterdam signified a landmark investment in the redevelopment of Katendrecht area. And although the newspapers, Rotterdam citizens and companies became a bit reproachful in 2008 when troubles appeared in full, they had provided their earlier support to this urban development initiative. There was very limited room for critical voices-for example the critical voice of local government council member Manuel Kneepkens, was not taken serious. And this moral support was not limited to Rotterdam; the initial plan was approved by the Ministry, and when in 2008 questions were asked about the project in the parliament and financial troubles were clear, the then minister praised the housing corporation for its initiative and guts. The minister took no real action-she had to resign later that year, her management of the SS Rotterdam case was an important motive for her discharge. In the Parliamentary investigation (Tweede Kamer 2014), it was concluded that the parties in the 2nd Chamber knew about the situation, but did not pay sufficient attention to the underlying issues such as governance and the role of the housing corporation.

There is a third layer of the psychic prison. Study of and writing about SS Rotterdam as a part of the Katendrecht urban renovation project, hardly exists. The modest urban impact report of SS Rotterdam (SEV 2010) is an exception. Because other housing corporations also run into troubles, the public and political discussions focused on governance, leadership and the political context of housing corporations, with SS Rotterdam as one of the cases.
The significance of SS Rotterdam for urban development has not been studied. Only recently a Master's student did a research on the revitalisation of Katendrecht area, from a rundown area with prostitution to a gentrified area (van der Ent 2015). And TU Delft student Zijlstra (2014, 50) made a contribution and commented: the (ex-) director and supervisory board member and project leader, remain silent. The media remain silent about the success or failure of the program, while there are clear signals that positive impacts can be detected. And the Rotterdam people remain silent; they shrug their shoulders and accept what happened. And the researchers remain silent; nobody wants to dig into this case anymore. Zijlstra is right, and this current silence can be seen as a signal of a large psychic prison-nobody wants to talk about it. The parliament has investigated the matter and why come back to a painful period that has become recent history anyway.

\section{Political system}

The metaphor of political system is interwoven with the metaphor of the psychic prison. Although the parliamentary investigation (Tweede Kamer 2014) shed light on the complex relationships, studies of the development of the (political) force field in the period 2002-2012 have not been made. Many parties have been involved in the course of the project. The powerful Port Authority of Rotterdam and the Municipality of Rotterdam wanted to solve a problem (they had approved the finance for the initial acquisition of the ship, the Port Authority became owner when the buyer-businessman went bankrupt) and were very pleased that a housing corporation was broadminded, entrepreneurial and willing to undertake a task in the redevelopment of Katendrecht area and that the corporation's director would act as a strong push factor. The ministry approved the SS Rotterdam plans. WSW (the national foundation giving guarantees to housing corporations) was involved and so were political parties, banks, the association of housing corporations, the community of urban planners, various commercial advisory firms and the media.

A parliamentary investigation (Tweede Kamer 2014) reconstructed the history of governance and decision making regarding SS Rotterdam, from a public governance approach and the focus was on what had gone wrong in decision making and supervision. It resulted in lessons could be learned with regards to formal responsibilities and resulted in conclusions about a new balance of power between housing corporations and the public sector.

The metaphor of the political system helps to understand the case of SS Rotterdam in the Katendrecht urban redevelopment context. But it needs a careful study and it is questionable whether this will be carried out. SS Rotterdam is considered 'finished business' after the 
parliamentary investigation. The ship now functions as a hotel, attracts visitors and has been kept for Rotterdam, and there is no practical need to undertake such study.

\section{Conclusions}

City making is complex. The case discussed of SS Rotterdam may have had huge budget overruns, but otherwise it is not so exceptional-at least, not in the Netherlands where every city has one or more big 'nightmare' projects in which things have gone very wrong. An exceptional projects are just one element of city making and urban studies. For complex questions, we need a more integral perspective to generate a more complete answer, than theories emerging from single metaphors can offer. This paper is a first effort to explore the potential of Morgan's metaphors from 'Images of Organization' (2006) for urban studies. ${ }^{6}$ The four metaphors used in the case study of SS Rotterdam throw different light on this case. The turmoil related to the management of SS Rotterdam distracts from the impact the icon had had on the urban redevelopment of the Katendrecht Area. The psychic prison appears to be a useful metaphor to grasp the situation. The concluding question of this article should be: does Morgan's set of 8 metaphors have value for urban studies? We think it is too early to firmly conclude that it does. No good answer can be given to the questions asked earlier in this article, namely: (1) which metaphors have most generative power and could together function as a set of root metaphors?; (2) how can metaphors be combined to generate better insights into urban questions?, and (3) which metaphors are less appreciated but could lead to meaningful understanding?

Our study has its limitations; we worked with only one case study and did not apply all metaphors. And there are other, deeper, questions too, about the use of metaphor. As an anonymous reviewer of the earlier version of this article suggested: this article uses metaphors to explain metaphors (like crossover, bridge) and that is how metaphors operate-they bring things together, and in a sense this is because of the very nature of metaphorsa 'squared' metaphor.' No good comment can be given to this remark-it requires more study. We tend to conclude that Morgan's set of metaphors has potentially added value for urban studies, especially for urban questions that can best be understood in an integral manner and that further exploration is a worthwhile undertaking. Often, urban theory is quite focussed and reveals in-depth information. However, there is also need for

\footnotetext{
${ }^{6}$ This article is based on Nientied and Banerjee (2016), but substantially revised and it includes just one case rather than three cases that were presented during the conference. Currently, a paper is written by Banashree Banerjee and the present author on two other case studies at a different level of abstraction: city making in Yangon, Myanmar and in Tirana, Albania.
}

broader perspectives. Liu (2012) for example examined the applicability of urban paradigms derived from Los Angeles school. Five metaphors-world city, cyber city, dual city, hybrid city and sustainable city-were examined against Shanghai's urban context. This provides an interesting broadened urban framework. Foley et al. (2014) argue for a rich blend of engaging narrative and rigorous analysis can provide decision makers with the various perspectives they need when making choices with long-range consequences for cities. Morgan's set of 8 metaphors have been related in this article to urban social studies (city making-what people do) rather than more technical studies. Morgan's set of metaphors is an instrument to give a broad, yet structured perspective. A multi-metaphor method would be suitable for questions that demand an integrated approach, like the questions of good public space, urban mobility, urban socio-economic integration, greener cities, and so on.

A metaphor can be interpreted differently in dissimilar urban conditions. This may be less 'objective', but does justice to the heterogeneity of cities. The urban policy realm in, say, Naples differs from the one in Rotterdam. The psychic prison metaphor may result in different outcomes in, say, Tirana and Rotterdam. Morgan's metaphors are 'root metaphors' and by no means a fixed and final set. Morgan (2016) suggests that scholars and practitioners go on with developing new metaphors. The set of 8 metaphors is not an all-encompassing theory in itself, and the names of the metaphors are not set in stone. Urban studies are characterised by the creative application of all sorts of metaphors. Perhaps the set of 8 metaphors, or another set, can inspire to bring some order, a nomenclature, in the current multitude of conceptual metaphors in urban studies. It is concluded too that further research on Morgan's metaphors in urban studies could be along three lines. First, the 8 root metaphors of Morgan can be systematically applied in studies of one single complex area or city development process that demands an integral. This can lead to a better understanding of the logic of the root metaphors-which metaphors have most generative power. Second, Morgan's metaphors may be a proven selection for organization theory, but that of course does not mean that this holds for urban studies too. Perhaps a modified set of metaphors works much better and experience with empirical studies could inform us on this point. Given the 1000 flowers that bloom, some order seems to be useful. Third, a better understanding of the use and genesis of significant metaphors would be useful. Metaphors like 'the city as a machine' and 'the city as organism' have been discussed in-depth, but others have not. Secchi (2014) suggests that metaphors should be interpreted as indices of ideologies behind them and are driven by the different parties that are involved in the development and transformation of 
the city. Understanding the genesis of city metaphors, may throw light on such notions behind the metaphor, which notions are behind the language and framing used.

\section{Competing interests}

The author declare that he has no competing interests.

\section{Author details}

${ }^{1}$ Polis University Tirana, Rruga Bylis 12, Autostrada Tiranë-Durrës, Km 5 , 1051 Tirana, Albania. ${ }^{2}$ Institute for Housing and Urban Development StudiesErasmus University Rotterdam, Rotterdam, Netherlands.

Received: 30 August 2016 Accepted: 15 October 2016

Published online: 24 October 2016

\section{References}

Barter N, Russel S (2013) Organisational metaphors and sustainable development: enabling or inhibiting? Sustain Account Manag Pol J 4(2):145-162 Baumann Z (2005) Liquid life. Polity Press, Cambridge

Beekmans J, de Boer J (2014) Pop-up city, city-making in a fluid world. BIS Publishers, Amsterdam

Bernstein A (2013) Cities as ideas. Harvard Business Rev. http://hbr. org/2013/04/cities-as-ideas

Bridge G, Watson S (eds) (2013) The new Blackwell companion to the city. Wiley, Chichester

Case P, Gaggiotti H (2014) Italo Calvino and the organizational imagination: reading social organization through urban metaphors. Cult Organ 22(2):178-198

Clegg S, Kornberger M, Pitsis T (2016) Managing \& organizations, and introduction to theory and practice. Sage, Los Angeles and London

Dúhr S, Colomb C, Nadin V (2010) European spatial planning and territorial cooperation. Abingdon Oxford, Routledge

Enderson T, Jayne M (eds) (2012) Urban theory beyond the west, a world of cities. Abingdon Oxford, Routledge

EU URBACT network (2016) Resilient Europe, urban resilience a concept for co-creating cities of the future. http://urbact.eu/sites/default/files/resilient_europe_baseline_study.pdf

Foley R, Darren P, Wiek A (2014) Imagining the future city. Issues Sci Technol 31 (1): 80. http://issues.org/31-1/imagining-the-future-city/

Franklin A (2010) City life. Sage, Thousand Oaks and London

Geary J (2012) I is an other, the secret life of metaphor and how it shapes the way we see the world. Harper Perennial, New York and London

Gerber A (2014) Introduction. In: Gerber A, Patterson B (eds) Metaphors in architecture and urbanism, an introduction. Transcript Verlag, Bielefeld and London, pp 13-32

Gerber A, Patterson B (eds) (2014) Metaphors in architecture and urbanism, an introduction. Transcript Verlag, Bielefeld and London

Gerrichhauzen L, Gruis V, Koolma R, van Schaar J (2014) Van lef en lof naar schade en schande: analyse van ontspoord leiderschap bij zes corporaties. TPC 12(4):13-17

Gregory S (2012) Detroit is a blank slate: metaphors in the journalistic discourse of art en entrepreneurship in the city of Detroit. American Anthropological Association; Ethnography Praxis in Industry Conference 2012 Proceedings, p 217-233

Haar S (2007) The ecological city: metaphor versus metabolis. University of Illinois at Chicago, School of Architecture, Great Cities Institute. Publication Number GCP-07-05

Köveczes A (2010) Metaphor: a practical introduction. Oxford University Press, Oxford

Lakoff G, Johnson M (2003) Metaphors we live by. University of Chicago Press, Chicago

Latham A (2008) Cities (2002): Ash Amin and Nigel Thrift. In: Hubbard P, Kitchin $R$, Valentine $G$ (eds) Key texts in human geography. Sage, Thousand Oaks and London, pp 215-224

Laundry C (2008) The creative city, a toolkit for urban innovators. Earthscan, London
Lemstra W (2004) Onderzoeksrapport garantieverstrekkingen HavenbedrijfOnderzoeksrapport Lemstra. Municipality of Rotterdam, Rotterdam

Liu CY (2012) From Los Angeles to Shanghai: testing the applicability of five urban paradigms. Int J Urban Reg Res 36(6):1127-1145

Magee L (2016) Interwoven cities. Palgrave Macmillan UK, Basingstoke

Martinez F (2014) The invisible city: exploring the third something of urban life. Cult Unbound J Curr Cult Res 6(3):647-669

Meager S (2015) The politics of urban knowledge. City 19(6):801-819

Mehmood A (2010) On the history and potentials of evolutionary metaphors in urban planning. Plan Theory 9(1):63-87

Morgan G (2006) Images of organization. Sage, Thousand Oaks and London (first edition: 1986)

Morgan G (2011) Reflections on images of Organization and its implications for organization and environment. Organ Environ 24(4):459-478

Morgan G (2016) Commentary: beyond Morgan's eight metaphors. Hum Relat 69(4):1029-1042

Newell J, Cousins J (2015) The boundaries of urban metabolism: towards a political-industrial ecology. Prog Hum Geogr 39(6):701-728

Nientied P, Banerjee, B (2016) A multi-metaphor approach to reading the city - a crossover. Paper presented at Conference 'Moving Cities: Contested Views on Urban Life', European Sociological Association, Krakow, 29 June-1 July

Paddison R, McCann E (eds) (2014) Cities \& social change, encounters with contemporary urbanism. Sage, Thousand Oaks and London

Parker S (ed) (2015) Urban theory and the urban experience, encountering the City. Abingdon Oxford, Routledge

Pickett S, Cadenasso M, Grove J (2004) Resilient cities: meaning, models, and metaphor for integrating the ecological, socio-economic, and planning realms. Landsc Urban Plan 69:369-384

Programmabureau NPRZ (2015) Handelingsperspectief wijk Katendrecht. Rotterdam

Scott A, Storper M (2015) The nature of cities: the scope and limits of urban theory. Int J Urban Reg Res 39(1):1-15

Secchi B (2014) A new urban question 3: when, why and how some fundamental metaphors were used. In: Gerber A, Patterson B (eds) Metaphors in architecture and urbanism, an introduction. Transcript Verlag, Bielefeld and London, pp 123-132

SEV (2010) De maatschappelijke effecten van De Rotterdam geordend en beschouwd. Rotterdam. http://sev.platform31.nl/publicaties/publicatie. asp?code pblc $=974$

Skivko M (2013) Fashion metaphors for the city, the discourse of urban representation by fashion phenomenon. Planum J Urban 27(2):1-5

Solesbury W (2013) World cities, city worlds: explorations with metaphors, icons and perspectives. Matador, Kibworth Beauchamps Leicester

Stieber N (2012) Metaphor and metropolis. Netherlands Institute for Advanced Study in the Humanities and Social Sciences, Wassenaar. Uhlenbeck Lecture 30

Thibodeau P, Boroditsky L (2011) Metaphors we think with: the role of metaphor in reasoning. PLoS ONE 6(2):e16782. doi:10.1371/journal. pone.0016782

Todolí J (2007) Disease metaphors in urban planning. CADAAD J 1(2):51-60

Tweede Kamer der Staten Generaal (2008) Woningbouwcorporaties, Verslag van een algemeen overleg. Kamerstuk $29453 \mathrm{nr} 94$. The Haque

Tweede Kamer der Staten Generaal (2009) Woningbouwcorporaties, Verslag van een algemeen overleg. Kamerstuk $29453 \mathrm{nr} 115$. The Hague

Tweede Kamer der Staten General (2014) Parlementaire enquête Woningcorporaties, Deelrapport Casussen. Kamerstuk 33606 nr 6. The Hague

van der Ent N (2015) Wij hadden een lange adem, een onderzoek naar de revitalisering van de Rotterdamse wijk Katendrecht, 1968-2015. Master's thesis History S0826049, Leiden University

Van Es R, van Rossum J (eds) (2016) De stad als organisatie. Vakmedianet, Deventer

Vullings R, Heleven M (2015) Not invented here, cross industry innovation. BIS Publishers, Amsterdam

Wu N, Silva E (2011) Urban DNA: exploring the biological metaphor of urban evolution with DG-ABC Model. Proceedings The 14th AGILE International Conference on Geographic Information Science. Utrecht University

Zijlstra S (2014) De wal en het schip. BOSS Magazine 49:42-51 